\title{
Evaluation of serological response of chicks against angara disease agent through indirect haemaglutination test
}

\author{
Shahzad Akbar Khan ${ }^{1 *}$, Tarique Hussain ${ }^{2}$, Muhammad Akhtar Qureshi ${ }^{1}$, Gulzar Ahmed ${ }^{1}$, \\ Sarfaraz Ali Fazlani ${ }^{3}$, ljaz Ahmed ${ }^{4}$ and Farhan Anwar Khan ${ }^{4}$ \\ ${ }^{1}$ Department of Veterinary and Animal Sciences, University of Azad Jammu and Kashmir, Pakistan. \\ ${ }^{2}$ National Institute for Biotechnology and Genetic Engineering, Faisalabad, Pakistan. \\ ${ }^{3}$ Faculty of Veterinary Sciences, Lasbella University of Agriculture, Water and Marine Sciences, Uthal, Pakistan. \\ ${ }^{4}$ N.W.F.P Agriculture University, Peshawar. Pakistan.
}

Accepted 24 August, 2011

Indirect Haemaglutination test is a reliable quantitative serological test for measuring antibodies against angara disease. The etiological agent contained in the liver of affected chick did not directly haemaglutinate erythrocyte of chickens. The antibody titre measured through IHA varied from 1:8-1: 128, in the sera (samples) of experimentally infected chickens at days 7, 14 and 21 post vaccination.

Key words: Haemagglutination, titre, sera, angara disease.

\section{INTRODUCTION}

Hydropericardium hepatitis syndrome (HHS) was first recognized in broiler flocks in Angara Goth (Goth means small town or village) near Karachi Metropolitan City of Pakistan, in the Province of Sindh (Jaffery, 1988). The disease was initially referred as "Angara Disease". The disease was then spread within six months in all densely populated broiler growing areas of the country. The outbreak of the disease was also recorded during 1989 in the highly poultry producing states of Mexico (Borrego and Soto, 1995).

In the light of present work on the serological response of broilers to vaccines against angara disease using indirect haemaglutination and adsorption of bacterial/viral sonicated material to the erythrocytes and subsequent haemaglutination of treated erythrocytes by specific antibody (Rahman et al., 1987) to identify the Angara Disease agent antibodies present in the convalescent serum samples of chicks. In this report indirect haemaglutination technique was adopted that produced highly encouraging results.

\section{MATERIALS AND METHODS}

Rearing of chicks

One hundred and fifty day old broiler chicks were reared at National Veterinary Laboratory (NVL), Islamabad under standard husbandry conditions. At the age of day 20 the chicks were divided into five groups $\mathrm{K}, \mathrm{L}, \mathrm{M}, \mathrm{N}$ and $\mathrm{O}$, each group having 30 chicks. On the same day, the chicks of groups $\mathrm{K}, \mathrm{L}, \mathrm{M}$, and $\mathrm{N}$ were vaccinated with ADVac-I, ADVac-II, ADVac-III and ADVac-IV, respectively (Table 2). The chicks of group $O$ were kept as non-vaccinated control. Route and dose of vaccination was adopted according to manufacturer's instructions (Table 2). The serum samples from chicks of groups K, L, M, N and O were also obtained at days 7, 14 and 21-post vaccination for serological investigations.

\section{Preparation of antigen}

A $40 \%$ suspension of affected frozen liver of chickens, infected with Angara Disease was prepared in phosphate buffered saline through use of ultrasound vibration for $7 \mathrm{~min}$. The suspension was then centrifuged at $5000 \mathrm{rpm}$ for $15 \mathrm{~min}$. The supernatant was collected and filtered by 0.22 -micron membrane filter.

\section{Sensitization of erythrocytes}

Human (Blood group O) and sheep erythrocyte were prepared 
Table 1. Composition of vernal buffer.

\begin{tabular}{lc}
\hline Sodium chloride & $42.5 \mathrm{~g}$ \\
Barbituric acid & $2.875 \mathrm{~g}$ \\
Sodium diethyl barbiturate & $1.875 \mathrm{~g}$ \\
Magnesium sulphate & $1.018 \mathrm{~g}$ \\
Calcium chloride & $0.147 \mathrm{~g}$ \\
Distilled water & $1 \mathrm{~L}$ \\
\hline
\end{tabular}

Table 2. Angara disease vaccines prepared from chicken's liver and used during present study.

\begin{tabular}{clcccc}
\hline Groups of chicks & Vaccines used & $\begin{array}{c}\text { Age of } \\
\text { vaccination } \\
\text { (Days) }\end{array}$ & $\begin{array}{c}\text { Dose of } \\
\text { vaccination } \\
\text { (ml) }\end{array}$ & $\begin{array}{c}\text { Route of } \\
\text { administration of } \\
\text { vaccines }\end{array}$ & $\begin{array}{c}\text { No. of } \\
\text { chicks in } \\
\text { each group }\end{array}$ \\
\hline K & ADVac-I & 20 & 0.20 & S/C & 30 \\
L & ADVac-II & 20 & 0.20 & S/C & 30 \\
M & ADVac-III & 20 & 0.20 & S/C & 30 \\
N & ADVac-IV & 20 & 0.20 & S/C & 30 \\
O & Control (Unvaccinated) & - & - & S/C & 30 \\
\hline
\end{tabular}

separately by centrifugation of citrated blood taken from the donors. The erythrocytes were washed thrice with physiological saline solution and then sensitized as follows.

\section{Human $O$ erythrocytes}

A $2 \mathrm{ml}$ amount of antigen were mixed with $0.2 \mathrm{ml}$ of packed human $\mathrm{O}$ erythrocytes. After thorough mixing the antigen and the erythrocytes were placed at $37^{\circ} \mathrm{C}$ for one hour. The erythrocytes were then separated by centrifugation and washed with $5 \mathrm{ml}$ physiological saline solution. After which sufficient saline was added to give $1 \%$ suspension (Carter, 1995).

\section{Sheep erythrocytes}

A $0.75 \mathrm{ml}$ amount of packed sheep erythrocytes were mixed with 1 $\mathrm{ml}$ of 1:400 dilution of chromium chloride solution $(0.1 \mathrm{M}, \mathrm{pH} 6.8)$, furthermore, $2 \mathrm{ml}$ of vernal buffer and $2 \mathrm{ml}$ sonicated antigen was also added. The mixture was thoroughly mixed and then placed at room temperature for $10 \mathrm{~min}$. The erythrocytes were then separated by centrifugation and washed for three times with vernal buffer to give $1 \%$ suspension (Bansal et al., 1986) (Table 1).

\section{Indirect haemaglutination (IHA) test}

The haemagglutination was carried out separately with human blood (O) and sheep erythrocytes. Two fold serial dilution of serum samples were prepared with physiological saline solution in microtitration plate (U-shaped). Routinely $0.05 \mathrm{ml}$ of $1 \%$ sensitized erythrocytes suspension were added in each well containing 0.05 $\mathrm{ml}$ of serum dilution. Two control well contained $0.05 \mathrm{ml}$ sensitized erythrocytes only. The plates were taped then left at room temperature for 30 to $60 \mathrm{~min}$ after that a reading was taken. The plates were then placed in the refrigerator overnight and a second reading was made. A positive reaction consisted of marked haemaglutination, while negative showed an evidence of button formation at the bottom of the wells.

\section{RESULTS AND DISCUSSION}

Direct haemaglutination of emulsified liver extract of chickens, guinea pigs and rats erythrocytes could not occur which indicated that material did not contain haemaglutinating agent. Actually, this observation prompted the author to perform IHA test. The presence of disease causing agent in liver of affected birds had been recorded by various workers (Cheema et al., 1988). The sera of various groups of chickens gave variable results with IHA test indicative of variation in antibody levels. The results of IHA regarding antibody level with both human and sheep erythrocytes were similar with all the serum samples. All the serum samples of chickens under test had indirect haemaglutination titres varying from 1:8$1: 128$.

Sensitization of sheep erythrocytes without coupling agent (chromium chloride) was found to be unsatisfactory because sheep erythrocytes contain heterophile antigens. IHA test has been found to be rapid and simple technique for measuring the antibody level against Angara Disease agent. This technique can be adopted for screening the large number of sera in epidemiological studies of this disease. Owing to its inexpensive procedure it can also be used to evaluate the immune status of the chickens of all kinds of (diseased /normal).

Serum samples were collected from chicks of sub group $\mathrm{k}, \mathrm{I}, \mathrm{m}, \mathrm{n}$ and $\mathrm{o}$, were subjected to indirect haemagglutination test for antibodies titration against Angara Disease virus. Serum samples were collected from chicks at 7, 14 and 21 days post vaccination. Seven days post vaccination GMT titre was $1.87,1.37,1.75$, 1.25 and 0.5 in chicks of sub groups $\mathrm{k}, \mathrm{I}, \mathrm{m}, \mathrm{n}$ and $\mathrm{o}$, respectively (Table 3 ). Fourteen days post vaccination 
Table 3. Anti HPS- IHA-Antibody response of broiler chicks 07 days post vaccination.

\begin{tabular}{cccccccccccccc}
\hline \multirow{2}{*}{ Subgroups } & \multicolumn{1}{c}{ No. of wells } & \multicolumn{1}{c}{ GMT (Log2) } \\
\cline { 2 - 11 }$y$ & $\mathbf{1}$ & $\mathbf{2}$ & $\mathbf{3}$ & $\mathbf{4}$ & $\mathbf{5}$ & $\mathbf{6}$ & $\mathbf{7}$ & $\mathbf{8}$ & $\mathbf{9}$ & $\mathbf{1 0}$ & $\mathbf{1 1}$ & $\mathbf{1 2}$ & GMT \\
\hline $\mathrm{K}$ & 3 & 3 & 2 & & & & & & & & & & 1.87 \\
$\mathrm{~L}$ & 6 & 1 & 1 & & & & & & & & & & 1.37 \\
$\mathrm{M}$ & 3 & 4 & 1 & & & & & & & & & & 1.75 \\
$\mathrm{~N}$ & 6 & 2 & - & & & & & & & & & & 1.25 \\
$\mathrm{O}$ & 3 & 1 & - & & & & & & & & \\
\hline
\end{tabular}

Table 4. Anti HPS- IHA-Antibody response of broiler chicks 14 days post vaccination.

\begin{tabular}{cccccccccccccc}
\hline \multirow{2}{*}{ Subgroups } & \multicolumn{1}{c}{ No. of wells } & \multicolumn{1}{c}{ GMT (Log2) } \\
\cline { 2 - 11 } & $\mathbf{1}$ & $\mathbf{2}$ & $\mathbf{3}$ & $\mathbf{4}$ & $\mathbf{5}$ & $\mathbf{6}$ & $\mathbf{7}$ & $\mathbf{8}$ & $\mathbf{9}$ & $\mathbf{1 0}$ & $\mathbf{1 1}$ & $\mathbf{1 2}$ & GMT \\
\hline $\mathrm{K}$ & 3 & 2 & 1 & & & & & & & & & & 2.25 \\
$\mathrm{~L}$ & 2 & 2 & 4 & & & & & & & & & & 2.25 \\
$\mathrm{M}$ & 1 & - & 5 & & & & & & & & & 3.12 \\
$\mathrm{~N}$ & 4 & 1 & 1 & & & & & & & & & & 2.25 \\
$\mathrm{O}$ & 4 & 2 & 2 & & & & & & & 1.75 \\
\hline
\end{tabular}

Table 5. Anti HPS- IHA-Antibody response of broiler chicks 21 days post vaccination.

\begin{tabular}{|c|c|c|c|c|c|c|c|c|c|c|c|c|c|}
\hline \multirow{2}{*}{ Subgroups } & \multicolumn{12}{|c|}{ No. of wells } & \multirow{2}{*}{$\frac{\text { GMT (Log2) }}{\text { GMT }}$} \\
\hline & 1 & 2 & 3 & 4 & 5 & 6 & 7 & 8 & 9 & 10 & 11 & 12 & \\
\hline $\mathrm{K}$ & 1 & 2 & 4 & 1 & - & - & & & & & & & 2.62 \\
\hline L & 1 & 3 & 1 & 1 & 1 & 1 & & & & & & & 3.12 \\
\hline $\mathrm{M}$ & 2 & 1 & 3 & 1 & 1 & - & & & & & & & 2.75 \\
\hline $\mathrm{N}$ & 2 & 1 & 2 & 2 & 1 & - & & & & & & & 2.87 \\
\hline 0 & 3 & 1 & - & 2 & - & - & & & & & & & 2.16 \\
\hline
\end{tabular}

Table 6. Geometric mean titre of antibodies in the sera of chicks 7, 14 and 21 days post vaccination.

\begin{tabular}{clccc}
\hline $\begin{array}{c}\text { Experimental } \\
\text { sub-groups }\end{array}$ & $\begin{array}{l}\text { Vaccines } \\
\text { administered }\end{array}$ & $\begin{array}{c}\text { Mean antibody at day } \\
\text { 07 post vaccination }\end{array}$ & $\begin{array}{c}\text { Mean antibody at day } \\
\text { 14 post vaccination }\end{array}$ & $\begin{array}{c}\text { Mean antibody at day } \\
\text { 21 post vaccination }\end{array}$ \\
\hline K & AD Vac-I & 1.87 & 2.25 & 2.62 \\
L & AD Vac-II & 1.37 & 2.25 & 3.12 \\
M & AD Vac-III & 1.75 & 3.12 & 2.75 \\
N & AD Vac-IV & 1.25 & 2.25 & 2.87 \\
O & Unvaccinated & 0.50 & 1.75 & 2.16 \\
\hline
\end{tabular}

GMT titres were 2.25, 2.25, 3.12, 2.25 and 1.75 in chicks of sub-group $\mathrm{k}, \mathrm{I}, \mathrm{m}, \mathrm{n}$ and o respectively (Table 4). Twenty-one days post vaccination GMT titres were 2.62, $3.12,2.75,2.87$ and 2.11 in chicks of sub-group $\mathrm{k}, \mathrm{I}, \mathrm{m}, \mathrm{n}$ and o (Table 5). The cumulative results of antibody profile at 7,14 and 21 days post vaccination in chicks of subgroups $\mathrm{k}, \mathrm{l}, \mathrm{m}, \mathrm{n}$ and $\mathrm{o}$ are given in (Table 6).

Statistically, there was no significant differences among the titre after 7, 14 and 21 days of post vaccination. Also, there was no significant differences among the titres with in the groups, however numerically, there was difference in the mean values within the titres where post vaccination gave increased antibody titres as compared to non-vaccinated control. Antibody titres in the sera of chicks are in close agreements with the results of previous study (Tizard et al., 1992) who determined antibody titres varied from 1:4 to $1: 256$. The results can be supported partially with Rahman et al. (1997), who titrated the IHA antibodies in the convalescent sera of chickens in the same age group. 


\section{REFERENCES}

Bansal RP, Josin RC, Sharma B, Bandyopadhyay SK, Chandra U, (1986). Single radial haemolysis test for the detection of rinderpest antibody, Trop. Anim. Health Prod., 18: 133-136.

Borrego JL, Soto E (1995). Reporte de campo de une brote de hepatitis con cuerpos de inclusion $(\mathrm{HCl})$ en reproductoras peasadas a edad temprana. Proc. $20^{\text {th }}$ Ann. ANECA Conf., pp. 1-4.

Carter GR (1995). Studies on pasteurella multocida I: A haemagglutination test for the identification of serological types, Amer. J. Vet. Res., 16: 481-484.

Cheema AH, Dilshad KH, Anjum AD (1989). Indirect Haemagglutination test for detecting Angara Disease agent antibody. Ist Int. Conf. and Trade Show on Poultry Prod. Karachi. Feb. 27-Mar. 2.
Jaffery MS (1988). A treatise on Angara Disease of chicken published by the Pakistan Vet. Med. Association.

Rahman SU, Ashfaque M, Muhammad K, Husain I, Irfan M (1987). Preliminary trial on single radial haemolysis test for assaying antibody against pasteurella mltocida infection in bovine. Pak. Vet. J., 7(4): 117-118.

Rahman SU, Ashfaque M, Anjum AD, Sindhu TA (1997). Indirecthemagglutination test for detecting angara disease (hydropericardium syndrome) agent antibodies. Pak. J. Livestock Poult., 3: 176-178.

Tizard I (1992). An Introduction to Veterinary Immunology, 5nd Ed., W.B. Sounders Company, London, pp. 119-153. 